\title{
Ornamental potential and commercial quality of Anthurium solitarium grown in bamboo compost ${ }^{1}$
}

\author{
Mariana Quintas Maitan ${ }^{*}$ (D), Janie Mendes Jasmim² \\ 10.1590/0034-737X202067030004
}

\begin{abstract}
Anthurium solitarium Schott is a species that might be used both as potted plant and cut foliage, but it is indispensable to have an adequate substrate to achieve desirable growth and commercial standard. Thus, the present research aimed at evaluating the ornamental potential and commercial quality of Anthurium solitarium grown in bamboo compost. The experimental design was in randomized blocks, with six substrates and three replicates with five plants in each experimental plot. Seedlings were grown for 270 days in substrates containing different percentages (v:v) of bamboo compost (BC) and coconut fiber (CF): T1 (100\% CF), T2 (75\% CF + 25\% BC), T3 (50\% CF + 50\% BC), T4 (25\% CF + 75\% BC), T5 (100\% BC); and a control treatment, T6 - commercial substrate Basaplant ${ }^{\circledR}(100 \%$ CS). The number of leaves, the leaf area, leaf (LDW) and root dry weight (RDW), root length and volume, LDW/RDW ratio and total dry weight. Leaf nutrient contents were determined. The ornamental potential, commercial acceptance and quality of the plants were also evaluated. Plants grown in substrates with BC showed higher growth, ornamental potential, market quality and acceptance than those grown in CF and CS.
\end{abstract}

Keywords: Araceae; organic residue; substrate; tropical crops.

\section{INTRODUCTION}

The world market for ornamental plants is eager for innovation. The biodiversity of the Brazilian flora includes plants whose ornamental potential has not been fully exploited yet (Castro et al., 2010), and data on growing them in a crop system would help their introduction to the market; besides they could be become alternatives to improve the income of small and medium size producers (Tombolato, 2008). It is also important to establish the management conditions to attain suitable growth and development, so that their ornamental potential can be fully expressed and commercial quality and acceptance can be attained.

Anthurium solitarium Schott is an epiphyte or terrestrial plant native to Brazil found in the ombrophilous forest, either under shade or on rocks exposed to full sun, with obovate (most rarely lanceolate) coriaceous leaf blades that can range from 32 to $107 \mathrm{~cm}$ in length, and from 8 to $40 \mathrm{~cm}$ in width, with a deep green color, presenting undulated leaf margins, blooming year round, thriving most frequently in the territorial area from Bahia to Rio de Janeiro states, Brazil (Valadares et al., 2010; Valadares et al., 2016), which confer the plant an overall appearance that might be appealing to the ornamental plant market.

One of the important factors for the growth and development of plants in containers is the substrate, which is the physical environment for the root growth of potted plants. The substrate must provide support to the plants, regulating the availability of water and nutrients to the roots, and also allowing gas exchanges (Kämpf, 2000).

Altland \& Krause (2012) reported that the physical characteristics of bamboo make it a promising alternative material for replacing Douglas fir in the composition of

Submitted on December 03 ${ }^{\text {rd }}, 2019$ and accepted on May 11 th, 2020.

${ }^{1}$ This work is part of the master's thesis of the first author and it was funded by Coordenação de Aperfeiçoamento de Pessoal de Nível Superior (CAPES)

${ }^{2}$ Universidade Estadual do Norte Fluminense Darcy Ribeiro, Departamento de Fitotecnia, Campos dos Goytacazes, Rio de Janeiro, Brazil. marianaquintasm@gmail.com; janie@uenf.br *Corresponding author: marianaquintasm@gmail.com 
substrates for growing plants. Martinez (2002) pointed out that in most cases no single material is an ideal substrate by itself, because it is difficult to find all the desirable characteristics in only one material, thus, the need for the use of mixtures, or even organic composts. Organic composts are made of at least two different materials, usually residues, which are combined and, after composting, originate a suitable material to be used for different purposes in agriculture, such as: enhancing desirable physical and chemical characteristics of soils, being used as substrate (or in the composition of a substrate) mainly for horticultural purposes Martinez (2002), among others.

Thus, the present research aimed at evaluating bamboo compost as a substrate for growing Anthurium solitarium determining the ornamental potential, market quality and acceptance of the plants.

\section{MATERIAL AND METHODS}

The experiment was carried out in a shade house, in Campos dos Goytacazes, Rio de Janeiro, Brazil, at $21^{\circ} 44^{\prime} 47^{\prime \prime}$ S, $41^{\circ} 18^{\prime} 24^{\prime \prime} \mathrm{W}$, from August 2016 to April 2017.

Seedlings were obtained by seed germination in polystyrene trays with 128 cells, containing the

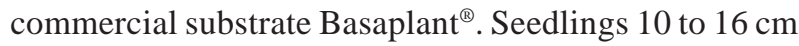
high, with four completely expanded leaves were used in a randomized block experiment, with six substrates, three replicates with five pots per plot. The seedlings were transferred to black plastic pots (L20) with holding capacity of 3,3 L. The substrates consisted of bamboo compost (BC), produced with ground bamboo and poultry litter $(1: 1 ; \mathrm{v}: \mathrm{v})$ and composted for six months, mixed to different percentages (v:v) of coconut fiber (CF), with an average length of two centimeters, so that the treatments were: $\mathrm{T} 1(100 \% \mathrm{CF}), \mathrm{T} 2(75 \% \mathrm{CF}+25 \% \mathrm{BC})$, $\mathrm{T} 3(50 \% \mathrm{CF}+50 \% \mathrm{BC}), \mathrm{T} 4(25 \% \mathrm{CF}+75 \% \mathrm{BC}), \mathrm{T} 5(100 \%$ $\mathrm{BC})$, and a control treatment with the commercial substrate Basaplant $^{\circledR}$, T6 (100\% CS).

Bamboo compost was obtained by composting poultry litter with chopped Bambusa vulgaris for four months. The compost piles were kept in an open warehouse area protected against rainfall during the entire composting period.

The substrates were subjected to physical and chemical analyses to determine their bulk and true densities, and total porosity (Kiehl, 1979), as well as the content of available macro and micronutrients, $\mathrm{pH}$ and electrical conductivity (Saturated Media Extract- SME, Warncke, 2011). The nitrogen content in the substrate water extract was determined by Nesslerization (Jackson, 1965); whereas the contents of phosphorus, potassium, calcium, magnesium, sulfur, manganese, iron, copper, boron and zinc were determined by atomic absorption spectrometry coupled to ICP-9000 (Shimadzu).

Throughout the experimental period, the plants were irrigated so that the humidity of each substrate was not lower than $80 \%$ of its maximum holding capacity (saturation).

At 270 days of growth under the experimental conditions, the number of leaves was determined. Six plants of each treatment were randomly taken and split into shoots and roots for determining: the total leaf area after scanning leaves with a bench leaf area meter LI- 3100 LI-COR); the leaf dry weight (LDW), the root dry weight (RDW), and plant total dry weight (TDW) and the LDW/ RDW ratio (LDW/RDW); the root length and volume after scanning the roots with a Scanner (EPSON Expression $10000 \mathrm{XL}$ ) and analyzing them with the software WinRHIZO $^{\mathrm{TM}}$ (Regents Instruments Inc.); and the leaf macronutrient contents.

Plant roots and shoots were dried in a convection oven at $70^{\circ} \mathrm{C}$ for 48 hours and weighed in in a precision laboratory balance to obtain their dry weights. After drying, leaves were ground in a Wiley mill and subjected to digestion before determination of their macronutrient contents as described above for the content of nutrients in the substrates.

The commercial quality, acceptance and ornamental potential of $A$. solitarium plants were evaluated taking two plants per plot from each replicate of each of the previously described treatments (substrates). The commercial quality of $A$. solitarium plants grown in different substrates was evaluated by 22 different referees, using a survey questionnaire for each plant and attributing scores from 0 to 10 to the following plant characteristics: PC1- Plant symmetry, distribution and proportionality in the pot, PC2- Leaf size and shape, PC3- Leaf color, brightness and texture, PC4- Plant overall appearance. Means of the scores attributed by the evaluators for each characteristic of an individual plant were used for statistical analysis

The ornamental potential of the plants was also surveyed using a questionnaire applied to 22 referees asking whether they liked $A$. solitarium or not, what they liked or disliked about it (and to what extent), if they thought the species is original as compared to other ornamental plants, what they found most/least attractive about it, and, finally, if they would buy the plants.

Data were subjected to analysis of (ANOVA) using the software R (F test); means of quality data were compared by Tukey test (Pd"0.05), and quantitative data were subjected to regression analysis and Dunnett test. Descriptive statistics was used for the ornamental potential data. 


\section{RESULTS AND DISCUSSION}

The results of the physical properties of the substrates are shown in Table 1. The total porosity of substrates varied from 76.21 to $98.50 \%$ (Table 1). These values are within the range established as adequate by Kämpf (2000), who reported that the total porosity of a substrate must be higher than it is in the soil, and it should be between 70 and $90 \%$. Concerning anthurium growth, Holcroft \& Laing (1995) observed good growth of Anthurium andreanum in a substrate with $82.7 \%$ porosity.

The true density values found were from 1.41 to $1.71 \mathrm{~g}$ $\mathrm{cm}^{-3}$, and are within the ranges of suitable porosity of materials and density of particles for substrates, as defined by De Boodt \& Verdonck (1972). The true density of a substrate is inversely correlated to its porosity, when the true density increases to such a degree that the porosity is much reduced, the plant root growth is impaired (Singh \& Sinju, 1998). Holcroft \& Laing (1995) observed that a substrate presenting a porosity value of $46 \%$ and a low percentage of small particles impaired the growth of anthurium plants, indicating that the water retention capability of the substrate caused the restriction in plant growth.

The substrate density and porosity values were relatively equilibrated (Table 1), except for T1, which showed a rather low $\mathrm{BD}$; the data on substrates containing bamboo compost corroborate the findings of Altland \& Krause (2012), who considered that the physical characteristics of ground bamboo made it a suitable material to be used in the composition of substrates for growing plants.

The $\mathrm{pH}$ values of substrates containing bamboo compost were in the range of 6.75-7.60, slightly basic and higher than the values recommended in the literature for A. andreanum (5.0-6.5). The $\mathrm{pH}$ values of $\mathrm{T} 1$ and $\mathrm{T} 6$ are within the $\mathrm{pH}$ range recommended for growing $A$. andreanum (Table 2) by Ozçelik \& Ozkan (2002); Dufour \& Guérin (2005).

The substrate $\mathrm{pH}$ affects the nutrient availability and the plant supply of all essential nutrients, and it interferes in the plant physiological processes and in the biology of microorganisms in the substrate (Ludwig et al. 2014). Although some authors recommend $\mathrm{pH}$ 5.0- 6.5 for growing Anthurium andreanum (Ozçelik \& Ozkan, 2002; Dufour \& Guérin, 2005.

The electrical conductivity (EC) of the substrates containing bamboo compost (Table 2) are considered adequate accordance with the recommended values for the cultivation of the for growing Anthurium andreanum in substrates, which vary from 1.0 to $1.5 \mathrm{dS}$ m-1 (Ozcelik \& Ozkan, 2002).

The macro and micronutrient contents in the substrates with bamboo compost were higher than those found by Sorace et al. (2013) in substrates for growing mini Anthurium (Table 2). The same authors also found that the highest plant growth was obtained in the substrate with the highest nutrient contents (a mixture of coconut fiber, pinus bark and rice husk).

Anthurium growth does not demand high nutrient levels when the plant is in its habitat, but in a nursery environment it is necessary to have a suitable growing media and a balanced fertilizer routine (Caldari Junior, 2004), thus, the importance of chemical properties of the substrate. Plants of $A$. solitarium grown in T2, T3, T4 and T5 did not show visual symptoms of nutrient deficiencies, but plants in T1 and T6 were chlorotic, and they also showed reduced growth as compared to the plants in the substrates with bamboo compost (Figure 1, 3)

The number of leaves, leaf area, leaf and root dry weights, root length and volume, LDW/RDW ratio, and total dry weight of Anthurium solitarium plants were significantly increased, in a quadratic manner, according to the increase of bamboo compost percentage in the substrates (Figure 2), with better results than observed for plants in $\mathrm{T} 1$ and $\mathrm{T} 6$.

These results could be related to the mixture of bamboo compost and coconut fiber providing more adequate, and balanced, aeration and water retention that might have enhanced energy yield leading to better plant growth as compared to plants in T1 and T6.

Plants in T3 produced the highest number of leaves (11 leaves), with a maximum estimate of 11.6 leaves (Figure 2). The highest root dry weight was observed in plants from T2 $(18.17 \mathrm{~g})$, and T4 plants presented the highest root length $(446.425 \mathrm{~cm})$ and volume $\left(4625.72 \mathrm{~cm}^{3}\right)$.

Table 1: Physical characteristics of substrates used in the experiment

\begin{tabular}{lcccccc}
\hline Characteristics & \multicolumn{7}{c}{ Treatments } \\
\hline Physical & T1 & T2 & T3 & T4 & T5 & T6 \\
Bulk density $\left(\mathrm{g} \mathrm{cm}^{-3}\right)$ & 0.03 & 0.29 & 0.33 & 0.30 & 0.37 & 0.38 \\
True density $\left(\mathrm{g} \mathrm{cm}^{-3}\right)$ & 1.58 & 1.47 & 1.59 & 1.41 & 1.71 & 1.62 \\
Total porosity $(\%)$ & 98.50 & 80.13 & 78.41 & 78.78 & 78.49 & 76.21 \\
\hline
\end{tabular}

*T1 - 100\% Coconut fiber (CF), T2 - 75\% CF + 25\% Bamboo compost (BC), T3 - (50\% CF + 50\% BC), T4 - (25\% CF + 75\% BC), T5 - (100\% BC), T6 - commercial substrate Basaplant ® (100\% CS). 
Plants grown in $100 \%$ coconut fiber (T1) did not significantly differ in leaf area, leaf dry weight, root length, root volume, root dry weight, LDW/RDW ratio, and plant total dry weight from plants grown in the commercial substrate (T6) according to Dunnet test (pd"0.05). Besides, plants from both substrates showed impaired growth and chlorotic leaves (Figure 1, 2, 3).

Morais et al. (2017) studying the potential of four accesses of Anthurium plowmanii, A. raimundii, A. bonplandii e A. affine as cut leaf observed that the mean leaf yield of the plants varied from 6.6 (A. plowmanii) to 10.5 (A. bonplandii) in 12 months of growth. In the present research the leaf yield was similar yield to that reported by Morais et al. (2017) but in nine months of growth. According to the same author, species of the Araceae family have slow growth as a typical characteristic, nevertheless, different from data observed in the present research.

Table 2: Chemical characteristics of substrates used in the experiment

\begin{tabular}{lcccccc}
\hline \multirow{2}{*}{ Characteristics Chemical } & \multicolumn{7}{c}{ Treatments } \\
\cline { 2 - 7 } & T1 & T2 & T3 & T4 & T5 & T6 \\
\hline $\mathrm{pH}(\mathrm{H} 2 \mathrm{O})$ & 5.90 & 7.00 & 7.00 & 7.20 & 7.70 & 5.30 \\
$\mathrm{CE}\left(\mathrm{dS} \mathrm{m}^{-1}\right)$ & 0.26 & 1.00 & 1.11 & 1.32 & 1.37 & 0.42 \\
$\mathrm{NH}_{4}^{+}\left(\mathrm{g} \mathrm{kg}^{-1}\right)$ & 0.32 & 0.35 & 0.33 & 0.47 & 0.46 & 0.05 \\
$\mathrm{NO}_{3}^{-}\left(\mathrm{g} \mathrm{kg}^{-1}\right)$ & 0.00 & 4.41 & 5.09 & 6.35 & 6.84 & 0.05 \\
$\mathrm{P}\left(\mathrm{g} \mathrm{kg}^{-1}\right)$ & 0.37 & 1.10 & 1.03 & 1.57 & 1.68 & 0.01 \\
$\mathrm{~K}\left(\mathrm{~g} \mathrm{~kg}^{-1}\right)$ & 0.78 & 2.75 & 2.77 & 3.31 & 3.44 & 0.38 \\
$\mathrm{Ca}\left(\mathrm{g} \mathrm{kg}^{-1}\right)$ & 0.05 & 1.21 & 1.84 & 2.17 & 0.55 \\
$\mathrm{Mg}\left(\mathrm{g} \mathrm{kg}^{-1}\right)$ & 0.04 & 0.55 & 0.58 & 0.74 & 1.04 & 0.64 \\
$\mathrm{~S}\left(\mathrm{~g} \mathrm{~kg}^{-1}\right)$ & 0.06 & 1.62 & 2.03 & 2.65 & 3.58 & 1.24 \\
$\mathrm{~B}\left(\mathrm{mg} \mathrm{kg}^{-1}\right)$ & 1.23 & 0.85 & 0.75 & 1.82 & 1.50 & 1.58 \\
$\mathrm{Zn}\left(\mathrm{mg} \mathrm{kg}^{-1}\right)$ & 1.05 & 3.89 & 3.93 & 4.01 & 4.44 & 2.22 \\
$\mathrm{Cu}\left(\mathrm{mg} \mathrm{kg}^{-1}\right)$ & 0.26 & 1.04 & 1.36 & 1.53 & 1.66 & 0.09 \\
$\mathrm{Fe}\left(\mathrm{mg} \mathrm{kg}^{-1}\right)$ & 1.95 & 2.80 & 2.90 & 4.05 & 1.27 \\
$\mathrm{Mn}\left(\mathrm{mg} \mathrm{kg}^{-1}\right)$ & 0.84 & 4.22 & 4.18 & 4.14 & 6.65 & 1.25 \\
\hline
\end{tabular}

*T1 - 100\% Coconut fiber (CF), T2 - 75\% CF + 25\% Bamboo compost (BC), T3 - (50\% CF + 50\% BC), T4 - (25\% CF + 75\% BC), T5 - (100\% BC), T6 - commercial substrate Basaplant ® (100\% CS). *Nutrient contents were determined in water extracts obtained using the Saturated Media Extract (SME) methodology.

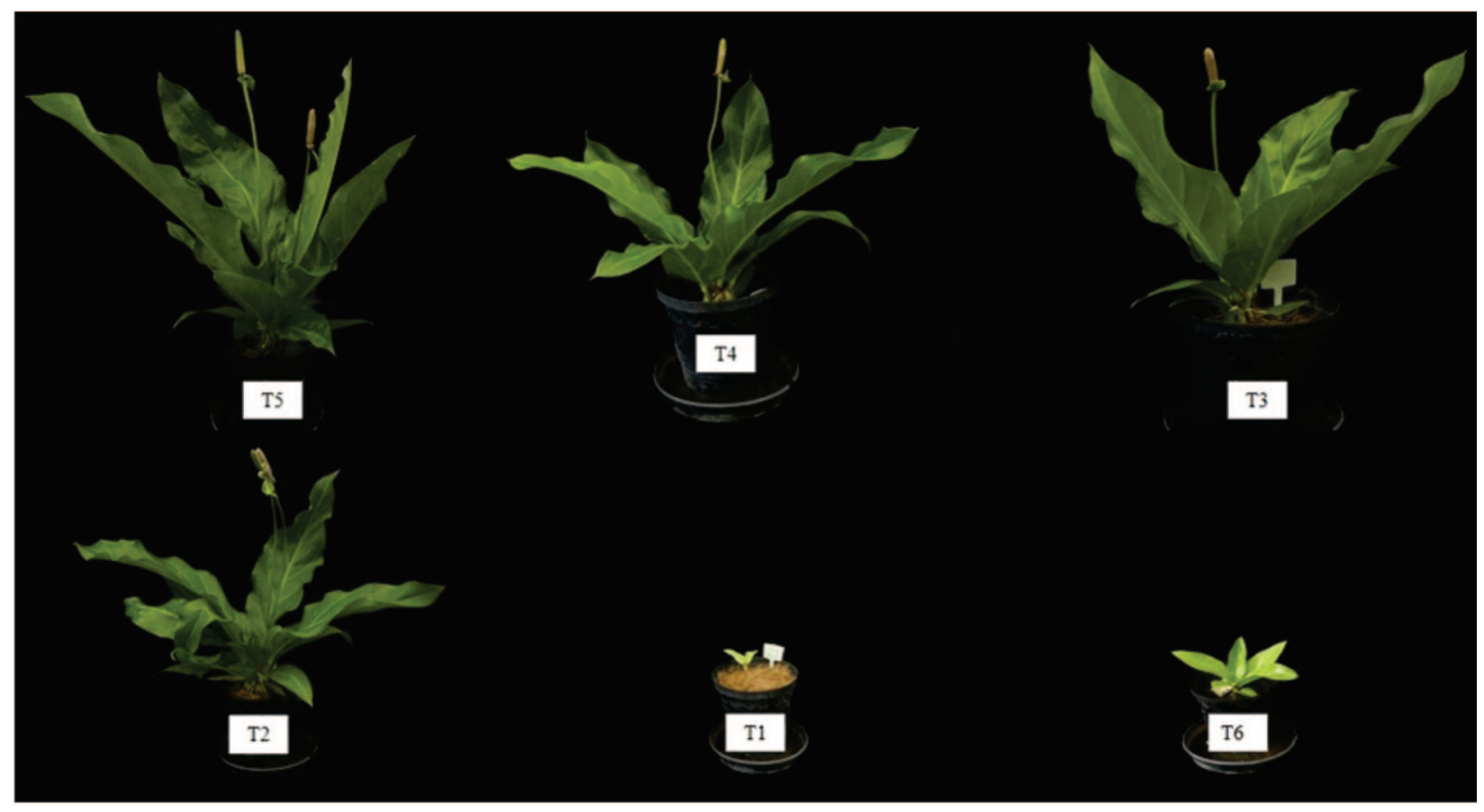

Figure 1: Plants of Anthurium solitarium grown for 270 days in $\mathrm{T} 1-100 \%$ Coconut fiber (CF), $\mathrm{T} 2-75 \% \mathrm{CF}+25 \% \mathrm{Bamboo}$ compost $(\mathrm{BC}), \mathrm{T} 3-(50 \% \mathrm{CF}+50 \% \mathrm{BC}), \mathrm{T} 4-(25 \% \mathrm{CF}+75 \% \mathrm{BC}), \mathrm{T} 5-(100 \% \mathrm{BC}), \mathrm{T} 6-$ commercial substrate Basaplant ${ }^{\circledR}$ $(100 \%$ CS).

Rev. Ceres, Viçosa, v. 67, n.3, p. 191-198, may/jun, 2020 
Freitas et al. (2010) reported that plants of A. affine grown in a mixture of sand + coconut fiber + cattle manure showed higher leaf size, total leaf area and number of leaves as compared to the plants grown in a mixture of sand + coconut fiber, pointing out the importance of organic in the composition of substrates for growing plants of the genus Anthurium.

Due to the lack of references indicating the adequate leaf nutrient contents for $A$. solitarium, the macronutrient
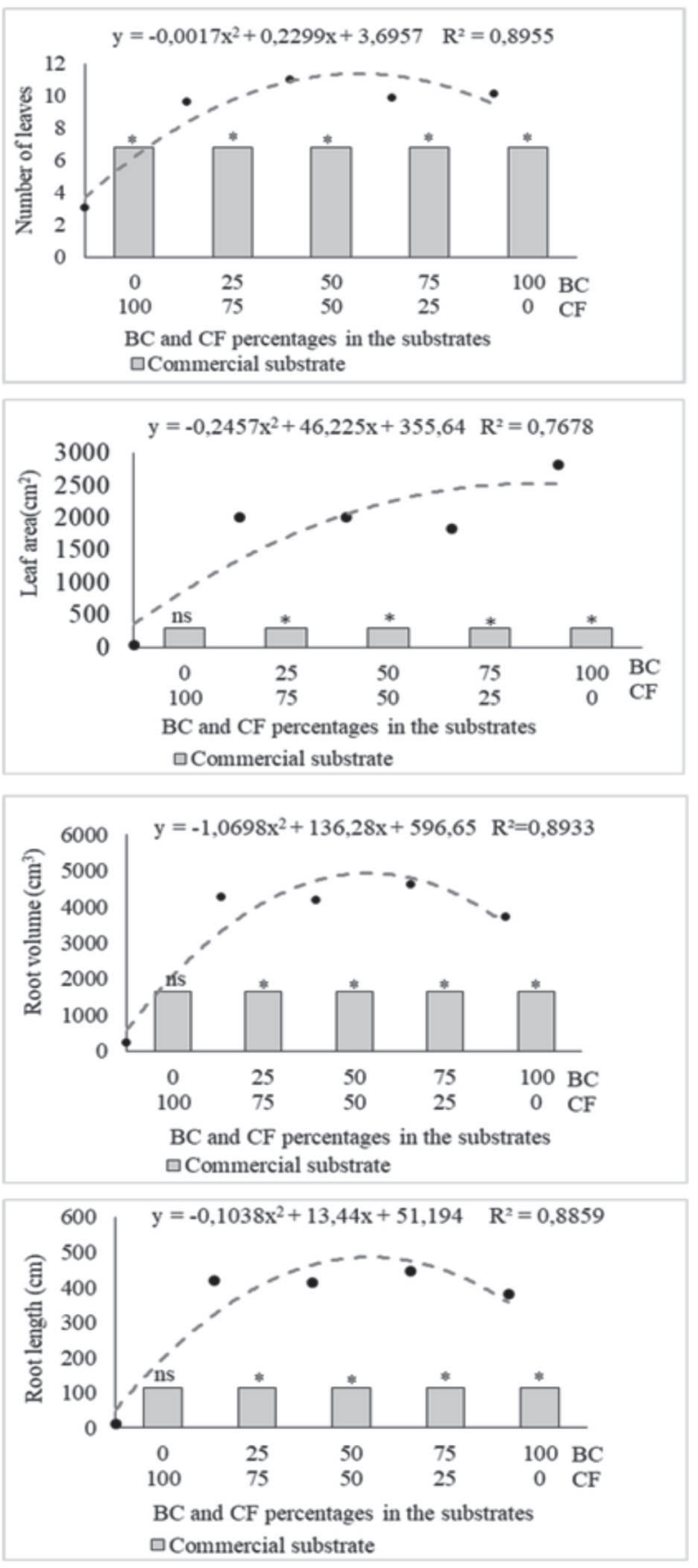

content ranges described for $A$. andreanum were used as reference standards (Tombolato et al., 1996) in $\mathrm{g} \mathrm{kg}^{-1}$ as follows: $\mathrm{N}$ (16-30); $\mathrm{P}(2-7) ; \mathrm{K}(10-35)$; $\mathrm{Ca}$ (12-20); $\mathrm{Mg}(5-10)$ e $S(1,6-7,5)$.

Plants grown in T5 had higher nitrogen contents (N) than plants from the other substrates (Figure 3). The leaf $\mathrm{N}$ content of plants in T2, T3, T4 and T5 were within the ranges considered adequate for Anthurium andreanum, whereas the $\mathrm{N}$ leaf content of plants in $\mathrm{T} 1$ and $\mathrm{T} 6$ were
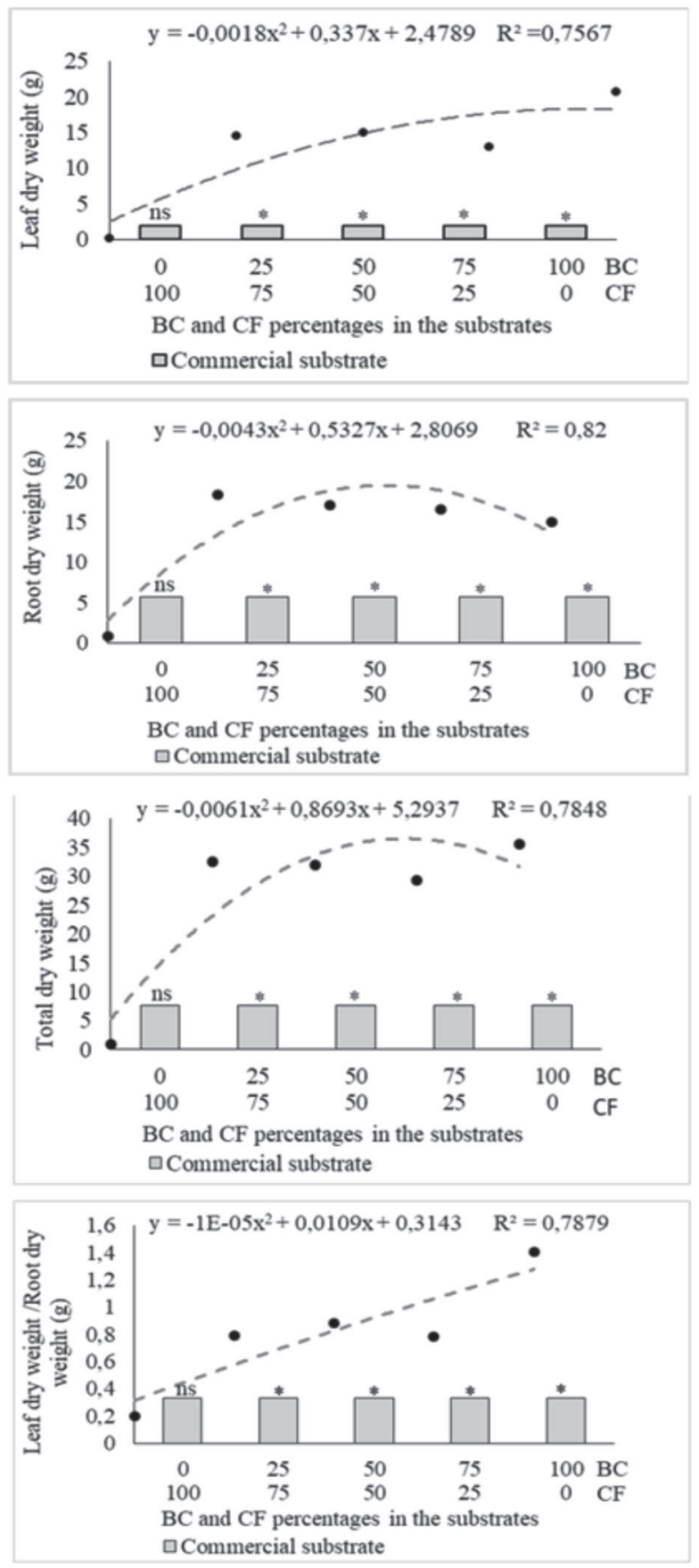

Figure 2: Number of leaves, leaf area, leaf dry weight(LDW), root length, root volume, root dry weight (RDW), LDW/RDW ratio, and total dry weight of Anthurium solitarium grown for 270 days in T1 - 100\% Coconut fiber (CF), T2 - 75\% CF + 25\% Bamboo compost $(\mathrm{BC}), \mathrm{T} 3-(50 \% \mathrm{CF}+50 \% \mathrm{BC}), \mathrm{T} 4-(25 \% \mathrm{CF}+75 \% \mathrm{BC}), \mathrm{T} 5-(100 \% \mathrm{BC}), \mathrm{T} 6-$ commercial substrate Basaplant ${ }^{\circledR}$ $(100 \%$ CS). 
not (Figure 3). Plants in all substrates containing bamboo compost showed steady growth along the experimental period, with good plant symmetry, high leaf green color intensity and brightness, corroborating the adequate $\mathrm{N}$ content data (Figure 2, 3).

Plants grown in T1 and T6 had N leaf contents lower than those established as adequate for A. andreanum. They also showed reduced growth and their leaves were chlorotic (Figure 1,2) indicating N deficiency.

Plants grown in T1, T2, T3, T4 and T6 phosphorus (P) leaf contents did not differ significantly (Dunnett, pd"0.05) and were within the ranges considered adequate for A. andreanum, except for T1 plants (Figure 3), indicating that $\mathrm{T} 1$ was not suitable for growing $A$. solitarium under the experimental conditions tested, i.e., without supplementary fertilization during the growth period.
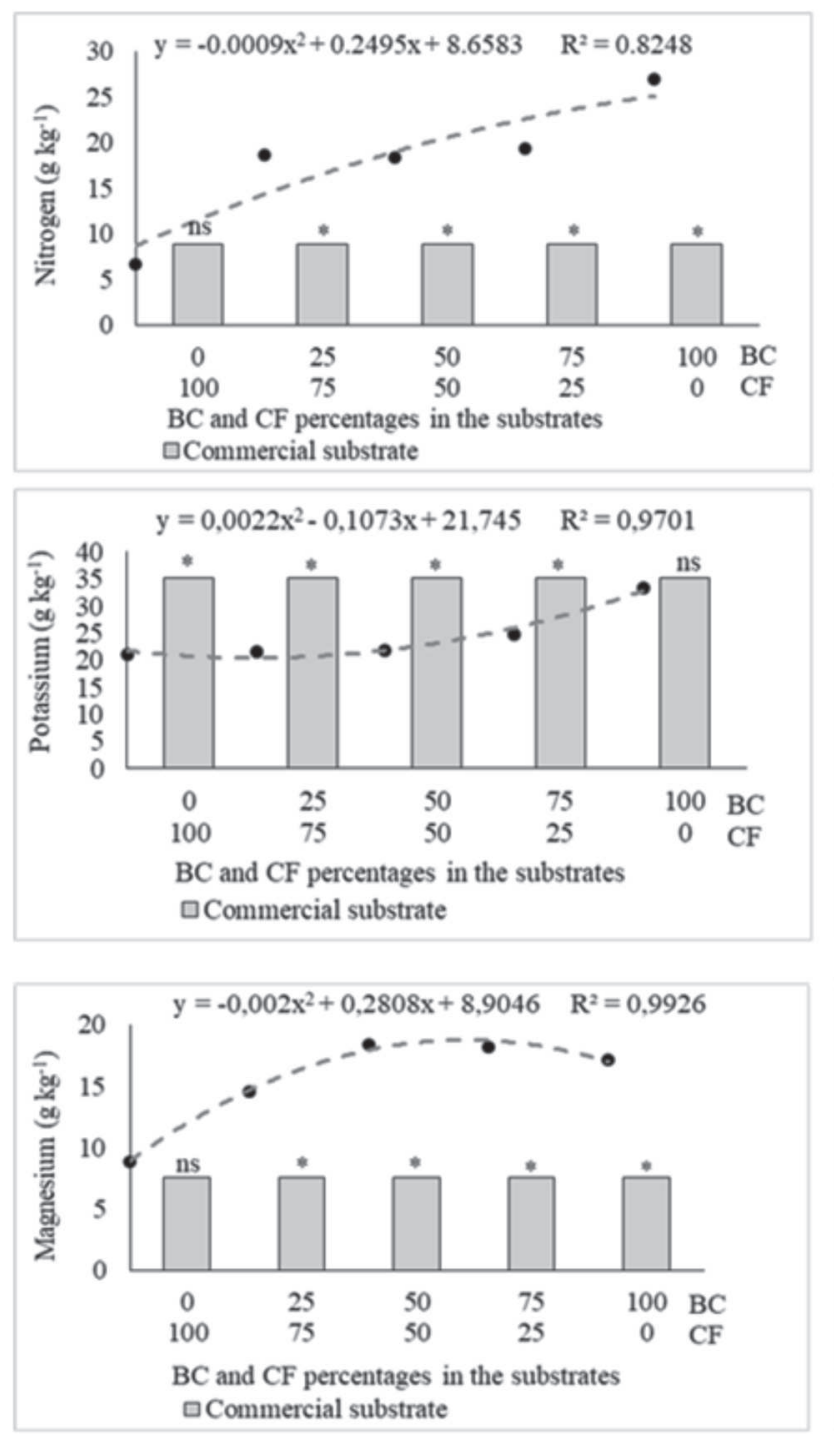

Potassium (K) leaf contents in the present study varied from 21.17 to $35.29 \mathrm{~g} \mathrm{~kg}^{-1}$ of dry weight (Figure 3). Potassium leaf contents in T5 and T6 plants did not differ significantly from each other and were higher than those observed in plants from the other treatments. Potassium leaf contents in all plants were within the ranges considered to be adequate and plants did not show any characteristic symptoms of K deficiency.

Plants of A. solitarium grown in T2, T3, T4 and T5 had adequate calcium (Ca) contents (Figure 3 ). Calcium leaf contents of plants grown in T1 and T6 did not differ from each other and were high above adequate levels, but plants were chlorotic, had a reduced root system and were smaller than plants from the other treatments (Figure 2, 3).

A. solitarium grown in $\mathrm{T} 2, \mathrm{~T} 3, \mathrm{~T} 4$ and $\mathrm{T}$ had magnesium $(\mathrm{Mg})$ leaf contents higher than those considered adequate, differing from the leaf contents of plants grown in $\mathrm{T} 1$ and
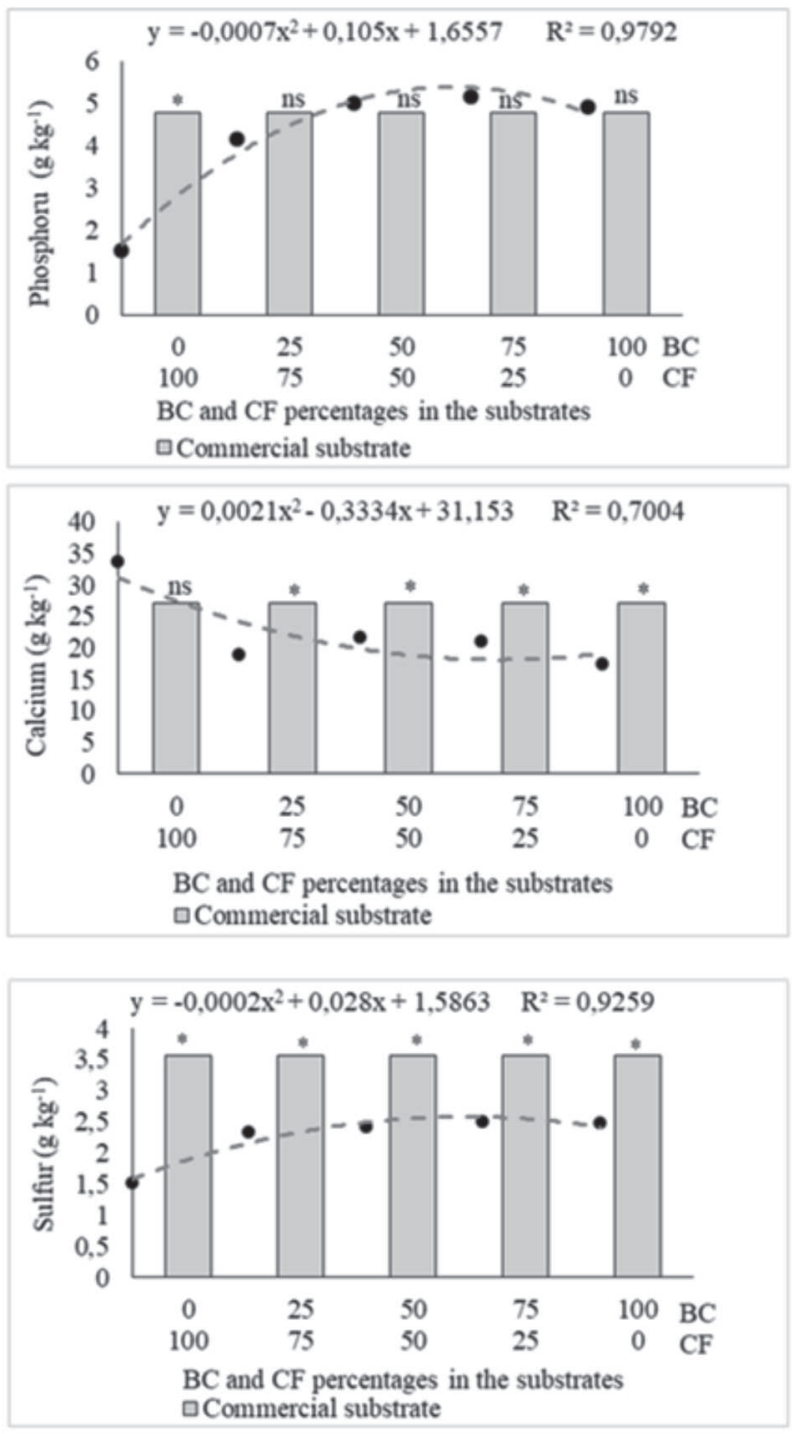

Figure 3: Nitrogen, phosphorus, potassium, calcium, magnesium, and sulfur contents in the leaves of A. solitarium grown for 270 days in $\mathrm{T} 1-100 \%$ Coconut fiber $(\mathrm{CF}), \mathrm{T} 2-75 \% \mathrm{CF}+25 \%$ Bamboo compost (BC), $\mathrm{T} 3-(50 \% \mathrm{CF}+50 \% \mathrm{BC}), \mathrm{T} 4-(25 \% \mathrm{CF}+75 \%$ BC), T5 - (100\% BC), T6 - commercial substrate Basaplant ${ }^{\circ}(100 \%$ CS).

Rev. Ceres, Viçosa, v. 67, n.3, p. 191-198, may/jun, 2020 
T6, whose values were adequate and did not significantly differ between themselves (Figure 3). Also, plants grown in $\mathrm{T} 1, \mathrm{~T} 2, \mathrm{~T} 3, \mathrm{~T} 4, \mathrm{~T} 5$ and $\mathrm{T} 6$ had adequate $\mathrm{S}$ leaf contents, sulfur leaf contents ranged from 1.6 to $3.57 \mathrm{~g} \mathrm{~kg}^{-1}$ of dry weight (Figure 3).

Although the $\mathrm{pH}$ values of substrates containing bamboo compost were slightly basic and higher than the values recommended in the literature, plant growth and leaf macronutrient contents were not negatively affected, corroborating reports that the $\mathrm{pH}$ of the substrate is not critical for the genus Anthurium as long as it does not impair the provision of nutrients to the plant (Criey, 1989).

Anthurium solitarium market quality results showed that plants grown in T2, T3, T4 and T5 had better plant symmetry, distribution and proportionality in the pot (PC1) than plants grown in T1 and T6 (Table 3); the same was observed for the plant overall appearance (PC4). Plants grown in $\mathrm{T} 1$ had lower means for PC1 and PC4 than plants grown in T6 (Table 3).

Ornamental plants must fulfil market quality standard demands, such as: beauty, good and compact plant overall appearance, and symmetry with good leaf distribution for covering the pot surface (IBRAFLOR, 2000). Plants grown in $\mathrm{T} 5$ had the highest leaf size and shape (PC2), and leaf color brightness and texture (PC3) means, but when the plant overall appearance was considered (PC4), they did not differ from plants in T2, T3 and T4 (Table 3). Plants grown in all substrates containing bamboo compost have a good ornamental potential as required by the ornamental market, considering that they had good evaluation results based on the characteristics highlighted by IBRAFLOR (2000).

Megersa et al. (2018) state that the balance plant/ recipient size is of major important since it strongly affects the overall appearance of the final product for the ornamental market, nevertheless Veatch-Blohm et al. (2012) emphasize that the leaf yield and quality define its commercial value

The growth of Anthurium solitarium in T1 and T6 did not yield quality plants for the ornamental plant market (Table 3), corroborating the growth and nutrient results, which in most cases were inferior to those obtained with the other substrates (Figure 2, 3).

The ornamental potential results showed that $81.81 \%$ of people who were interviewed said that: they liked plants in general, had plants at home and knew Anthurium species. Anthurium andreanum was the main Anthurium species mentioned by them $(94.73 \%)$; the other $5.26 \%$ consisted of different species. Fifty nine percent of the people said that $A$. solitarium is fairly attractive, whereas $41 \%$ of them said it is very attractive.

The results of the questionnaires also showed that the most attractive characteristics of the plant were as follows: the leaf texture and its deep green color (31\%), plant exuberance $(25 \%)$, leaf size and brightness $(25 \%)$, the undulated leaf margins (13\%), and the number of leaves $(6 \%)$ in the plant. On the other hand, the least attractive characteristics were the non- attractive inflorescence $(37 \%)$, the absence of (conspicuous) flowers $(27 \%)$, the plant size $(18 \%)$, the plant roots $(9 \%)$. And $9 \%$ of the referees said that the plants had no unattractive characteristic.

It was also observed that $18.18 \%$ of the referees evaluated the plant as very original due to its exuberance, symmetry, brightness, and leaf size, whereas, $81.81 \%$ qualified it as average in originality. Most of them (95.45\%) affirmed that they would by $A$. solitarium because it is attractive, rustic and suitable to different environments; $4.54 \%$ said they would not buy the plant either because they do not like any plants at all or due to the fact that they do not have enough room at home.

Table 3: Means of PC 1-Symmetry, distribution and proportionality of the plant in the pot, PC2- Leaf size and shape, PC3- Leaf color, brightness and texture, and PC4- Overall appearance of A. solitarium plants grown in substrates at 270 days of growth in a shade house

\begin{tabular}{lllll}
\hline Treatments & PC1 & PC2 & PC3 & PC4 \\
\hline T1 & $1.98 \mathrm{C}$ & $1.74 \mathrm{D}$ & $1.75 \mathrm{D}$ & $1.74 \mathrm{C}$ \\
T2 & $7.49 \mathrm{~A}$ & $7.54 \mathrm{~B}$ & $7.65 \mathrm{~B}$ & $7.68 \mathrm{~A}$ \\
T3 & $7.70 \mathrm{~A}$ & $7.73 \mathrm{~B}$ & $7.74 \mathrm{~B}$ & $7.78 \mathrm{~A}$ \\
T4 & $7.51 \mathrm{~A}$ & $7.62 \mathrm{~B}$ & $7.83 \mathrm{~B}$ & $7.78 \mathrm{~A}$ \\
T5 & $8.09 \mathrm{~A}$ & $8.05 \mathrm{~A}$ & $8.47 \mathrm{~A}$ & $8.39 \mathrm{~A}$ \\
T6 & $4.14 \mathrm{~B}$ & $3.69 \mathrm{C}$ & $3.51 \mathrm{C}$ & $3.82 \mathrm{~B}$ \\
\hline CV\% & 5.51 & 4.43 & 4.14 & 5.08
\end{tabular}

*T1 - 100\% Coconut fiber $(\mathrm{CF}), \mathrm{T} 2-75 \% \mathrm{CF}+25 \%$ Bamboo compost (BC), $\mathrm{T} 3-(50 \% \mathrm{CF}+50 \% \mathrm{BC}), \mathrm{T} 4-(25 \% \mathrm{CF}+75 \% \mathrm{BC}), \mathrm{T} 5$ - (100\% BC), T6 - commercial substrate Basaplant ® (100\% CS).

*Means followed by the same letter in the column do not statistically differ by Tukey test (p < 0.05$)$; means of 22 evaluations for each set of characteristic. 
The results indicate that $A$. solitarium grown in substrates with bamboo compost has high ornamental potential and good market quality and acceptance. The results of $A$. solitarium growth and nutrient contents indicate that nutrient content ranges considered adequate for $A$. andreanum can also be used for this species. In general, plants grown in T5 showed the highest growth values (Figure 2), leaf nutrient contents (Figure 3), and also highest quality evaluation scores (Table 3), therefore $100 \%$ of bamboo compost would be preferably recommended as substrate for growing A. solitarium.

\section{CONCLUSIONS}

The results led to the conclusion that bamboo compost can be used for growing Anthurium solitarium of good ornamental potential and fulfilling market quality standards recommended.

\section{ACKNOWLEDGEMENTS, FINANCIAL SUPPORT AND FULL DISCLOSURE}

This study was financed in part by the Coordenação de Aperfeiçoamento de Pessoal de Nível Superior - Brasil (CAPES) - Finance Code 001 and Fundação de Amparo à Pesquisa do Estado do Rio de Janeiro (FAPERJ). The authors declare that have no conflicts of interest.

\section{REFERENCES}

Altland JE \& Krause C (2012) Change in Physical Properties of Pine Bark and Switchgrass Substrates Over Time. Journal of Environmental Horticulture, 30:113-117.

Caldari Junior P (2004) Técnicas de cultivo do antúrio (Anthurium andraeanum). Revista Brasileira de Horticultura Ornamental, 10:42-44

Castro ACR, Morais EB, Mourão ICS, Carvalho ACPP \& Loges V (2010) Potencial de folhagem ornamental de acessos de antúrio. Acta Horticulturae, 855:61-68.

Criley RA (1989) Culture and cultivar selection for anthurium in Hawaii. Acta Horticulturae, 246:227-236.

De Boodt M \& Verdonck O (1972) The physical properties of the substrates in horticulture. Acta Horticulturae, 26:37-44.

Dufour L \& Guérin V (2005) Nutrient solution effects on the development and yield of Anthurium andraeanum Lind. in tropical soilless conditions. Scientia Horticulturae, 105:269282

Freitas RMO, Neto RVS, Dombroski JLD, Nogueira NW \& Câmara FAA (2010) Teste de diferentes substratos para cultivo de mudas de Anthurium affine Schott. Revista Verde de Agroecologia e Desenvolvimento Sustentável, 05:96-100.

Holcroft DM \& Laing MD (1995) Evaluation of pine bark as a substrate for anthurium production in South Africa. Acta Horticulturae, 401:177-183.

Ibraflor (2000) Instituto Brasileiro de Floricultura. Padrão Ibraflor de Qualidade. Campinas, Publicidade \& Marketing. 90p.

Jackson ML (1965) Soil Chemical Analysis. Englewood Cliffs, Prentice-Hall. 498p.
Kämpf AN (2000) Seleção de materiais para uso como substrato. In: Kämpf NA \& Fermino MH (Eds.) Substratos para Plantas: a base da produção vegetal em recipientes. Porto Alegre, Gênesis. p.139-146.

Kiehl EJ (1979) Manual de Edafologia: relações solo-planta. São Paulo, Ceres. 262p.

Ludwig F, Fernandes DM, Guerrero, AC \& Villas Bôas RL (2014) Características dos substratos na absorção de nutrientes e na produção de gérbera de vaso. Horticultura Brasileira, 32:184189.

Martinez PF (2002) Manejo de substratos para horticultura. In: Furlani AMC, Bataglia OC, Abreu CA, Abreu CA, Furlani PR, Guaggio JÁ, Minami K (Eds.) Caracterização, manejo e qualidade de substratos para produção de plantas. Campinas, Instituto Agronômico. p.53-76. (Documentos IAC, 70).

Megersa HG, Lemma DT \& Banjawu DT (2018) Effects of Plant Growth Retardants and Pot Sizes on the Height of Potting Ornamental Plants: A Short Review. Journal Horticulturae, $05: 220$.

Morais EB, Castro ACR, Aragão FAZ, Silva TF, Soares NS \& Silva JP (2017) Avaliação do potencial uso de folhagem de antúrio nativa. Horticultura Ornamental, 23:07-14.

Ozçelik A \& Ozkan CF (2002) EC and pH changes of the growing media and nutrient solution during anthurium production in closed system. Acta Horticulturae, 573:91-96.

Singh BP \& Sinju UM (1998) Soil physical and morphological properties and root growth. Horticulturae Sciencie, 33:966971.

Sorace M, Faria RT, Fonseca ICB, Sorace MAF, Fernandes FRM \& Ecker AEA (2013) Substratos para o cultivo de mini antúrio em vaso. Arquivos do MUDI, 01:23-24.

Tombolato AFC, Castro CEF, Graziano TT, Mathes LAF \& Furlani AMC (1996) Ornamentais e flores. In: Raij BV (Ed.) Recomendações de adubação e calagem para o Estado de São Paulo. Campinas, Instituto Agronômico \& Fundação IAC. p.207-218.

Tombolato AFC (2008) Potencial ornamental de espécies nativas. Revista Brasileira de Horticultura, 14:27-28.

Valadares RT, Martins MLL \& Coelho MAN (2010) O gênero Anthurium Schott (Araceae) no Parque Estadual Paulo César Vinha, Guarapari, Espírito Santo. Natureza on line, 08:107113.

Valadares RT \& Sakuragui CM (2016) A Família Araceae Juss. nas restingas do Estado do Espírito Santo. Boletim do Museu de Biologia Mello Leitão, 38:187-255.

Veatch-Blohm ME, MalinowskI M \& Keefer D (2012) Leaf water status, osmotic adjustment and carbon assimilation in colored calla lilies in response to saline irrigation. Scientia Horticulturae, 144:65-73.

Warncke D (2011) Recommended test procedures for greenhouse growth media. In: Northeast Coordinating Committee for Soil Testing (Ed.) Recommended Soil Testing Procedures for the Northeastern United States- Northeastern Regional Publication $\mathrm{N}^{\circ}$. 493. $3^{\text {rd }}$ Edition. Newark, University of Delaware Newark. p. $103-110$. 